\title{
Neuromarketing: Current Situation and Future Trends
}

\author{
María del Mar Lozano Cortés* and María García García \\ University of Extremadura (UNEX), Badajoz, Spain
}

Submission: August 14, 2017; Published: August 30, 2017

*Corresponding author: María del Mar Lozano Cortés, University of Extremadura (UNEX), Badajoz, Spain,

Email: mlozanoz@alumnos.unex.es

\begin{abstract}
To understand the usefulness of neuromarketing in business terms, one needs to understand how consumers behave during the purchasing process. Thanks to brain imaging, one can better understand what determines this behaviour, and the opinions and preferences of consumers [1]. However, according to [2], the ethical and moral implications underlying this activity require a judicious and socially responsible use of the information obtained. The method used is based on semi-structured interviews with seven Spanish neuromarketing firms. They were asked about the knowledge of both the population and Spanish firms, about the situation of the discipline versus traditional market research, and about the lack of specific regulations, among other things. The results demonstrate the incipient state of the discipline, although extensive growth is expected in the coming years.
\end{abstract}

Keywords: Neuromarketing; Current situation; Market research

\section{Introduction}

One of the fundamental objectives of the neurosciences lies in understanding the biological mechanisms responsible for man's mental activity, allowing knowledge to be gained on the processes occurring within the human brain, and thus find deeper explanations about the behaviour of people and their decision making. Emotions are also an essential part of neuromarketing. In fact, for Álvarez del Blanco [3], it is the most important motivating force known in humans. Zaltman [2] agrees that it is the primary force acting on the mental processes and behaviour.

According to Zaltman [2], most consumers make decisions based on irrational processes. The current homogenization of products, globalization of the economy, saturation of commercial information, and even online purchases require firms to advance in their understanding of consumer tastes so as to bring to market products that are more relevant. Numerous studies have confirmed that over $80 \%$ of new products coming to market end up failing in their first six months of life, or simply do not reach the objectives presupposed for them [1].

\section{Objectives and Methods}

The main objective of this research was to analyse the current state of the discipline of neuromarketing in Spanish territory, and to try to predict the future situation in the short term. To this end, the following specific objectives were set:
OBJ1: To investigate the level of demand for services related to the discipline that exists in the Spanish population and Spanish firms.

OBJ2: To determine the implementation of the tools of neuromarketing today.

OBJ3: To establish the relationship between neuromarketing and traditional market research.

To achieve the above objectives, a qualitative approach was made to the topic through an exploratory inquiry that was not intended to establish statistical generalizations, but to serve as a basis for future studies. Thus, virtual semi-structured interviews were conducted with a sample of 7 firms professionally connected with neuromarketing [4], with activity in Spain, and available for participation in the study.

\section{Results}

First, and to give a reasoned picture of the implementation of the discipline today, the study's participants were asked about what knowledge they thought the population (citizens) and firms of Spain have about neuromarketing. The results fall into three categories based on the observed level of knowledge (generalized ignorance, approach to the concept, and basic notions). Thus, the responses indicate a generalized ignorance of the discipline both among the firms (28.5\%) and the general population $(42.9 \%)$. 


\section{Open Access Journal of Neurology \& Neurosurgery}

Another of the questions posed alluded to how much firms expected from consumer neuroscience. In general, the purpose of any neuromarketing study is to analyse the responses of subjects when exposed to certain stimuli. However, the interviewees were asked about what kind of study firms tend to request, and with what specific goals. Their responses pointed mainly towards three goals: an effective business strategy design, improved communication with customers, and evaluation of new products or services, all with identical percentages (33.3\%) [5].

The study's participants were asked to describe the evolution that neuromarketing has undergone up to today. Because the history of neuromarketing is still short, one can say that the discipline is still in a "real introductory phase, via testing and the expansion of its use" (Firm no 6). Therefore, it is considered that the development and assimilation process will be somewhat slow and costly.

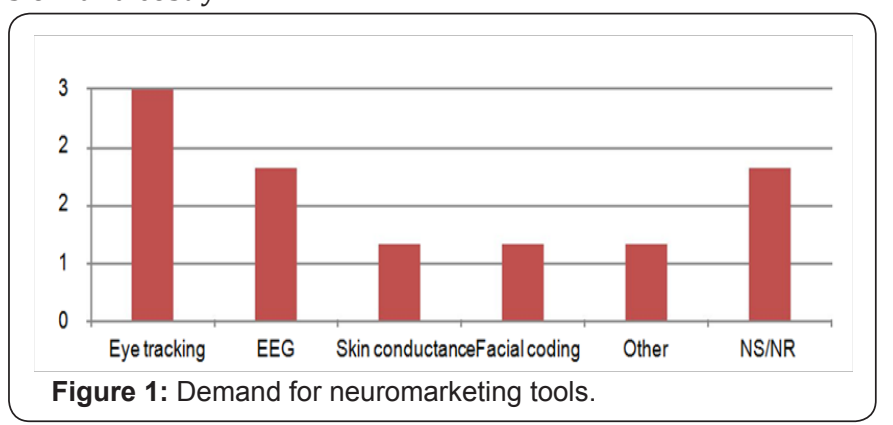

As for the tools used in neuromarketing, the participants were asked about the most effective technique for an average study. According to the responses analysed, the most effective tools are nuclear magnetic resonance imaging and encephalography. We obtained $28.5 \%$ for each technique. With respect to the technique that is most demanded, eye tracking and encephalography stand out over the rest (Figure 1). One appreciates an increase in demand for biometric or physiological techniques relative to the responses to the previous question.

Source: The authors. We also inquired into whether there is some benefit for firms offering neuromarketing services. To this question, $100 \%$ of the responses are positive, affirming that it creates greater understanding of the consumer, it encourages curiosity and the possibility of observing new effects and learning from them.

\section{Conclusion}

In relation to the degree of knowledge of the discipline, it was verified that it is still an unknown science for the vast majority of businesses and for citizens in general. Especially noteworthy is the association of neuromarketing with large firms, partly due to the cost of the studies which is regarded as a brake on the current implementation of the technique in SMEs. Thus, the cost of the technology is also confirmed as being the main obstacle to a science that is still "in a real introductory phase", since it represents a disbursement that not all firms can afford.

As for the relationship between traditional market research and neuromarketing, the responses indicate an equal coexistence of the two research methods, with that coexistence even becoming indispensable. Thus, the theoretical consolidation of the discipline faces two key issues. On the one hand, there is the development of a committed normative regulation understood by all as a guarantee against possible malpractice and misuse, ensuring the confidentiality and privacy of the results, and guaranteeing the rights of individuals. And on the other, there is the need to incorporate multidisciplinary professionals specialized in neuromarketing into companies' marketing and/ or communications departments.

\section{Referances}

1. Lindstrom M (2010) Buyology: verdades y mentiras de por qué compramos. Barcelona: Gestión 2000 1(1): 224.

2. Zaltman G (2003) Cómo piensan los consumidores: lo que nuestros clientes no pueden decirnos y nuestroscompetidores no saben Madrid: Empresa Activa, Spain, p. 389.

3. Álvarez Del Blanco R (2011) Neuromarketing, fusión perfecta: seducir al cerebro con inteligencia para ganar en tiempos exigentes. Madrid: Pearson Educación, Spanish.

4. Braidot N (2005) Neuromarketing: neuroeconomía y negocios. Madrid: Puerto Norte-Sur, Spain, P. 730.

5. Andreu Sánchez C, Contreras Gracia AY, Martín Pascual MÁ (2014) Situación del neuromarketing en España. El profesional de la información 23(2): 151-157.
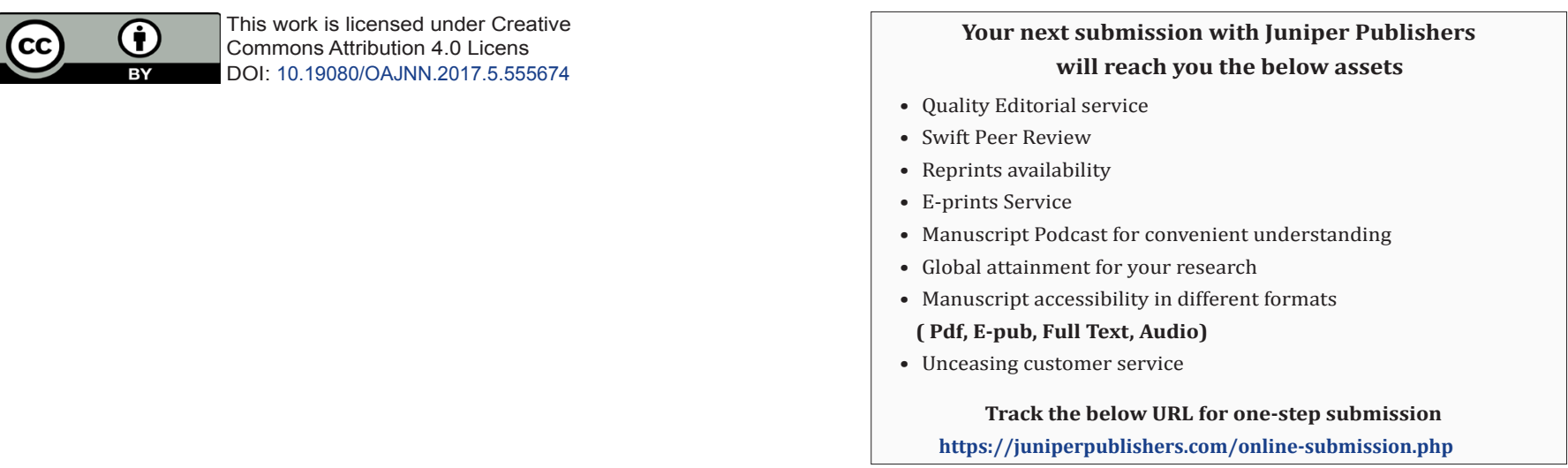